\title{
Actual and Potential Yield Levels of Potato in Different Production Systems of Japan
}

\author{
T. Deguchi ${ }^{1}$ - K. Iwama $^{2}$ - A. J. Haverkort ${ }^{3,4}$
}

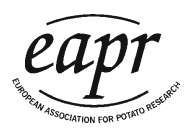

Received: 7 November 2015 / Accepted: 18 July 2016 /

Published online: 22 September 2016

(C) The Author(s) 2016. This article is published with open access at Springerlink.com

\begin{abstract}
Japan annually produces 2.4 million tons of potato on 79,700 ha. There are four cropping seasons stretching from $24^{\circ}$ to $45^{\circ} \mathrm{N}$ : a winter crop at Okinawa, spring and autumn crops at Kyushu and southern Honshu, and a single summer crop at Hokkaido. Using the crop growth model LINTUL-POTATO-DSS, actual yields were compared with potential yields. The spring and summer crop yields of all prefectures varied from 10 to $43 \mathrm{t} \mathrm{ha}^{-1}$ and were 16 tha $^{-1}$ on average (not weighted by area); the actual/potential yield ratio varied between 0.21 and 0.63 and was 0.40 on average (not weighted). Actual and potential yields of the autumn crops were half those of the spring crops. Actual yields of the Hokkaido summer crops in 21 years decreased from 35 to $32 \mathrm{tha}^{-1}$ because of a change of varieties whereas potential yield remained stable at $56 \mathrm{tha}^{-1}$. Increased temperature would reduce the potential yield to $53 \mathrm{tha}^{-1}$ but would move it up to $60 \mathrm{tha}^{-1}$ by lengthening the growing season and to $77 \mathrm{tha}^{-1}$ when the $\mathrm{CO}_{2}$ effect on growth is taken into account. The actual/potential yield ratio at Hokkaido was benchmarked against that of other growing regions in the world, showing that this area compares well with that of other efficient production systems in northern Europe and America.
\end{abstract}

Keywords Attainable yield $\cdot$ Climate change $\cdot$ Crop model $\cdot$ Latitude $\cdot$ Solanum tuberosum L. · Systems analysis

T. Deguchi

happy84potato@yahoo.co.jp

A. J. Haverkort

anton.haverkort@wur.nl

1 Hokkaido University of Education, Sapporo Campus, 5-3-1 Ainosato, Kita-ku, Sapporo 002-8502, Japan

2 Field Crops Science, Research Faculty of Agriculture, Hokkaido University, N9 W9 Kita-ku, Sapporo 060-8589, Japan

3 Wageningen University and Research Centre, Droevendaalsesteeg 1, Wageningen, The Netherlands

4 Department of Plant Production and Soil Science, University of Pretoria, Private Bag X20, Hatfield 0028, South Africa 


\section{Introduction}

Potato was first introduced to Japan (Nagasaki in Kyushu, the southern region of Japan) from Europe via Indonesia by traders of the Netherlands in about 1600 (Kawakami 1948; Uchida and Taguchi 1943). It may have been Solanum tuberosum ssp. andigena, since the introduction date was just after the introduction of potato from South America to Europe. It spread to the northern regions of Japan and was cultivated before the middle of the eighteenth century at Hokkaido. At the end of the nineteenth century, many potato varieties bred in Europe and the USA were introduced to Japan which were considered to be Solanum tuberosum ssp. tuberosum. Due to its south to north location (Fig. 1), potato is grown year-round, as a winter crop free from frost in Okinawa and a summer crop free from heat in Hokkaido. Between the two extremes, some prefectures grow a major spring and a minor autumn crop.

Figure 2 schematically shows the main potato-growing prefectures and the period with an average daily temperature window between 10 and $20{ }^{\circ} \mathrm{C}$. Although this period indicates a theoretically suitable season for potato growth, growers do not always follow it. In some regions, many growers advance planting dates by covering ridges with plastic film to heat the soil and sometimes covering whole plants with plastic film to reduce the temperature decline in the night (Fig. 3). Other reasons not to follow the temperature optimum for growing potatoes may be favourable market prices at premature harvest, the onset of the rainy season in June and July with unacceptable risks of late blight infection and also the need to evacuate the field for the next crop, mainly rice.

Almost $80 \%$ of the total potato production takes place at Hokkaido on farms of about 30 ha with about 5 ha of potato (Hokkaido Government 2015). Most of the work is mechanized except picking up behind the windrower at small farms.

Since 1887, the largest area of potato was cultivated in 1949, with an area of 235,000 ha with a yield of $11 \mathrm{t} \mathrm{ha}^{-1}$ (MAFF 2010). Since then, the production area was reduced at Honshu and Kyushu but remained fairly stable at Hokkaido where yields reached $41 \mathrm{t} / \mathrm{ha}$ in 2003. Presently, the total nationwide area is 79,625 ha with a total production of 2.4 million tons (Table 1). Hokkaido, with the highest yields, has $66 \%$ of the national area under potato but $78 \%$ of the national production. Kanto and Kyushu spring crops have the second highest yields of around $22 \mathrm{t} \mathrm{ha}^{-1}$. The autumn crops are important only at Kyushu with about 2000 ha and a yield of almost $20 \mathrm{tha}^{-1}$. At Okinawa, the winter crops are produced on 109 ha yielding $15.5 \mathrm{t} \mathrm{ha}^{-1}$, thus producing $1700 \mathrm{t}$ per year.

Table 2 shows the destination of the domestically produced crop and imports based on fresh potato equivalent. Over five decades, the total amount of potato consumption did not change much: table potato and starch decreased, while processed potato consumption as chips and French fries increased strongly. In 2010, $31 \%$ of processed potato was produced in Japan. In 2010, the bulk of starch production of 745,000 t went to starch for industrial and food usage, and 429,000 t was processed, mainly into crisps besides salads, frozen croquettes and French fries. Since the population of Japan is 127 million, potato consumption per capita in 2010 is $16.4 \mathrm{~kg}$ per year, of which $5.7 \mathrm{~kg}$ is fresh table potato.

As shown in Table 3, the most popular variety of table potato is Irish Cobbler (Danshaku-imo in Japanese) with $22 \%$ share in the total potato area, followed by May 


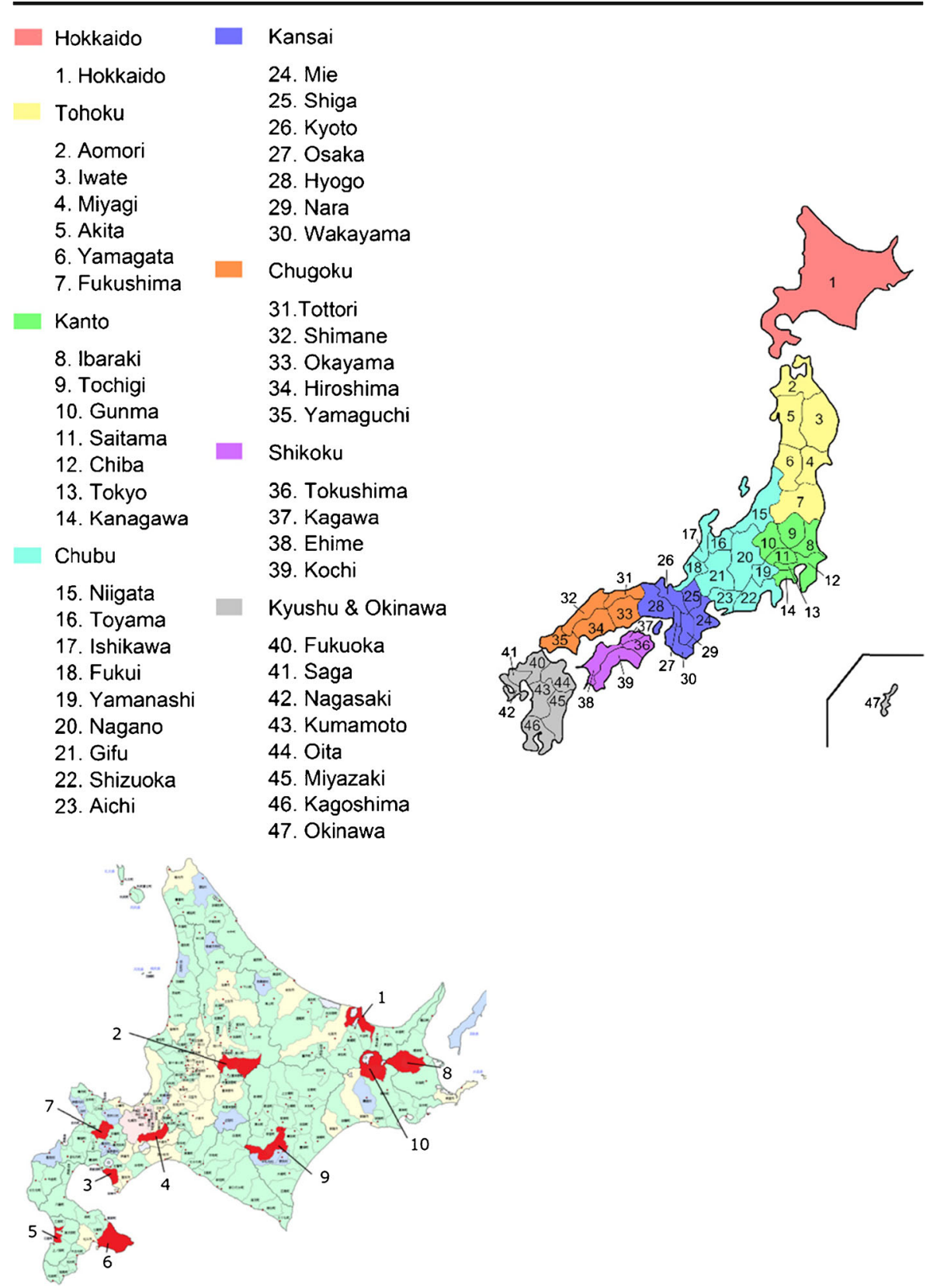

Fig. 1 Prefectures of Japan (top, names are in Table 5; https://commons.wikimedia.org/wiki/File:Regions and_Prefectures_of_Japan.png) and districts of Hokkaido (below, names are in Table 7; http://uub.jp/47 /hokkaido/map.html)

Queen. Of the starch potato varieties, Konafubuki with $19 \%$ of the total potato area is the most popular. Astarte and Early Starch are also grown in areas affected by potato cyst nematodes because of their tolerance. Of the processing potato varieties, Toyoshiro is the most popular with $11 \%$ of the total planted area. 


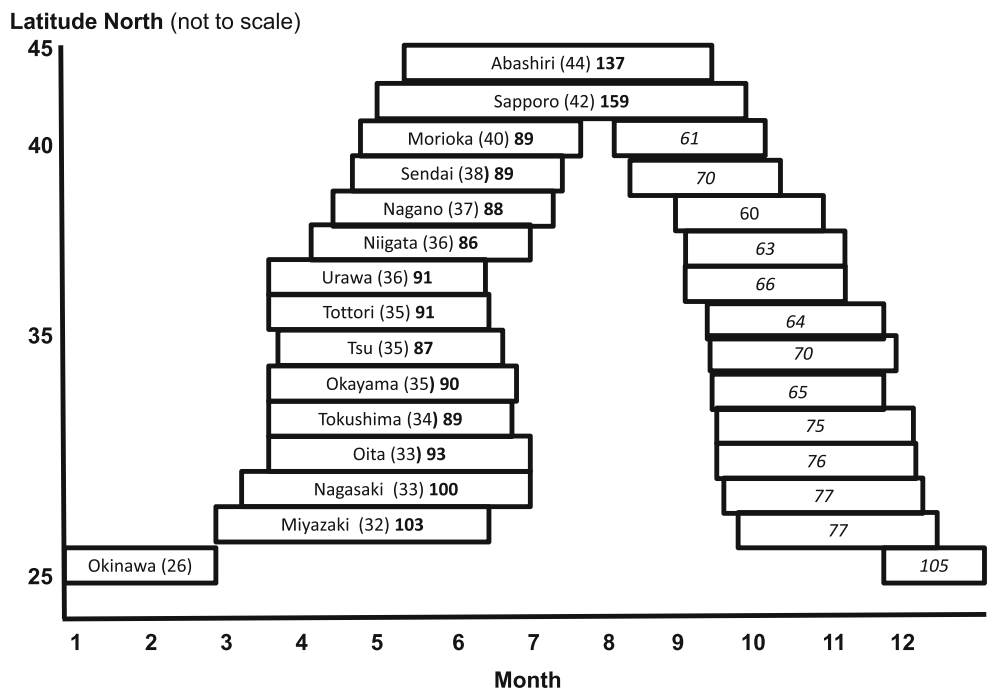

Fig. 2 Approximation of the lengths of the growing seasons in autumn and spring in different prefectures, defined by daily average temperatures being between 10 and $20^{\circ} \mathrm{C}$. Between brackets: degrees latitude north (after Kurihara et al. 1963). Okinawa is inserted by the authors of the present article

There are five potato breeding sites, three public ones organized by the central government and prefectures at Hokkaido and Nagasaki and two private ones operated by Hokkaido Agricultural Cooperative at Naganuma and the processing company Calbee at Nemuro at Hokkaido. Konafubuki was specifically bred for starch production. For local crisp production, Toyoshiro was bred and is used specifically for processing into crisps and French fries. The occurrence of golden potato cyst nematodes (Globodera rostochiensis) was first reported in 1972 (Mori et al. 1994), but recently, also invasion of white potato cyst nematodes (G. pallida) has been reported (MAFF 2015).

Basic seed production is also mainly publicly funded through eight stations for rapid multiplication followed by an efficient cut-off system with a limited number of five field generations (Kawakami et al. 2015).

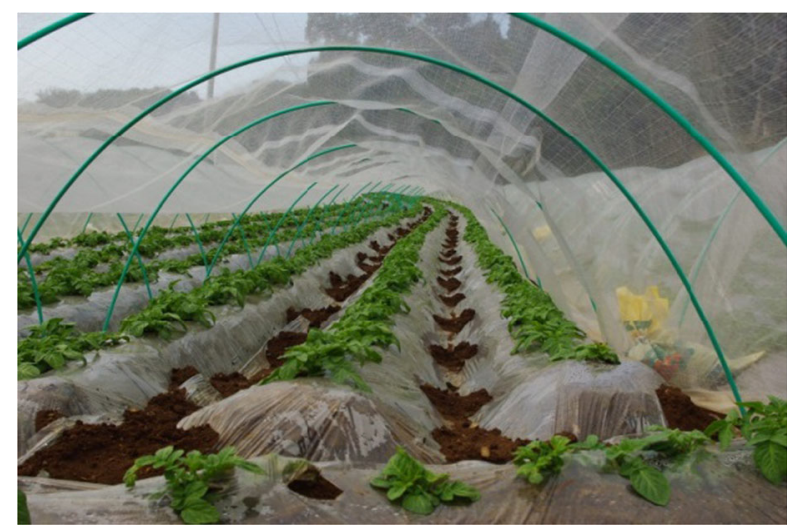

Fig. 3 Double layers of plastic to hasten spring crop emergence and enhance early development near Nagasaki at Kyushu 
Table 1 Potato production data in 2013 (MAFF 2015) of the regions shown in Fig. 1

\begin{tabular}{|c|c|c|c|c|c|c|c|c|c|}
\hline \multirow[t]{2}{*}{ Region } & \multicolumn{3}{|l|}{ Total } & \multicolumn{3}{|c|}{ Spring crops } & \multicolumn{3}{|c|}{ Autumn crops } \\
\hline & $\begin{array}{l}\text { Area } \\
\text { ha }\end{array}$ & $\begin{array}{l}\text { Production } \\
1000 \mathrm{t}\end{array}$ & $\begin{array}{l}\text { Yield } \\
\mathrm{t} \mathrm{ha}^{-1}\end{array}$ & $\begin{array}{l}\text { Area } \\
\text { ha }\end{array}$ & $\begin{array}{l}\text { Production } \\
1000 \mathrm{t}\end{array}$ & $\begin{array}{l}\text { Yield } \\
\mathrm{t} \mathrm{ha}^{-1}\end{array}$ & $\begin{array}{l}\text { Area } \\
\text { ha }\end{array}$ & $\begin{array}{l}\text { Production } \\
1000 \mathrm{t}\end{array}$ & $\begin{array}{l}\text { Yield } \\
\mathrm{t} \mathrm{ha}^{-1}\end{array}$ \\
\hline Total & 79,625 & 2408 & 30.2 & 76,829 & 2360 & 30.7 & 2796 & 47 & 16.9 \\
\hline Hokkaido & 52,400 & 1876 & 35.8 & 52,400 & 1876 & 35.8 & 0 & 0 & - \\
\hline Tohoku & 3897 & 68 & 17.4 & 3897 & 68 & 17.4 & 0 & 0 & - \\
\hline Kanto & 5282 & 117 & 22.2 & 5208 & 117 & 22.4 & 74 & 1 & 11.7 \\
\hline Chubu & 4217 & 71 & 16.8 & 4079 & 69 & 17.0 & 138 & 2 & 11.3 \\
\hline Kansai & 1288 & 13 & 10.5 & 1215 & 13 & 10.5 & 73 & 1 & 9.5 \\
\hline Chugoku & 1466 & 19 & 12.9 & 1132 & 16 & 13.7 & 334 & 3 & 10.1 \\
\hline Shikoku & 667 & 8 & 12.6 & 516 & 7 & 12.9 & 151 & 2 & 11.7 \\
\hline Kyushu & 10,408 & 235 & 22.5 & 8382 & 196 & 23.3 & 2026 & 39 & 19.3 \\
\hline
\end{tabular}

The aim of the study presented here was to compare actual and potential yield levels of the different production areas in Japan. The study should allow benchmarking the yield gaps of the various areas and seasons within the country. Special attention was given to the various potato-growing districts at Hokkaido. Also, as a second aim, the yield gaps observed in Japan were to be compared with those of other potato-growing regions of the world such as Europe, South Africa and North America. Thirdly, by assuming a $2{ }^{\circ} \mathrm{C}$ temperature increase and a $45 \%$ increase of the $\mathrm{CO}_{2}$ concentration as is often predicted (e.g. IPCC 2013), the modelling exercise aimed to explore the repercussions of climate change for potato production at Hokkaido.

Table 2 Changes in potato consumption $(\times 1000 \mathrm{t})$, proportion produced in Japan and consumption as food per capita during 50 years in Japan (MAFF 2015) ${ }^{\mathrm{a}}$

\begin{tabular}{|c|c|c|c|c|c|c|c|c|}
\hline \multirow[t]{2}{*}{ Year } & \multirow[t]{2}{*}{ Total } & \multirow[t]{2}{*}{ Table potato } & \multicolumn{2}{|c|}{$\begin{array}{l}\text { Crisps and French } \\
\text { fries }^{b}\end{array}$} & \multirow[t]{2}{*}{ Starch } & \multirow[t]{2}{*}{ Others $^{\mathrm{c}}$} & \multirow{2}{*}{$\begin{array}{l}\text { Percentage domestic } \\
\text { d } \\
(\%)\end{array}$} & \multirow{2}{*}{$\begin{array}{l}\text { Food per capita } \\
\text { (kg/year) }\end{array}$} \\
\hline & & & Domestic & Import & & & & \\
\hline 1960 & 3572 & 1635 & 0 & 0 & 1007 & 930 & 100 & 17.5 \\
\hline 1970 & 3605 & 1349 & 41 & 0 & 1365 & 850 & 100 & 13.4 \\
\hline 1980 & 3632 & 1165 & 364 & 211 & 1417 & 475 & 94 & 14.9 \\
\hline 1990 & 3942 & 1180 & 555 & 392 & 1280 & 535 & 90 & 17.2 \\
\hline 2000 & 3715 & 932 & 536 & 820 & 1023 & 404 & 78 & 18.0 \\
\hline 2010 & 3247 & 711 & 429 & 959 & 745 & 403 & 70 & 16.4 \\
\hline
\end{tabular}

${ }^{a}$ Crop statistics in MAFF (Ministry of Agriculture, Forest and Fishery in Japan, http://www.maff.go. $\mathrm{jp} / \mathrm{j} / \mathrm{seisan} /$ tokusan/imo/pdf/08.pdf)

${ }^{\mathrm{b}}$ Including potato powder

${ }^{\mathrm{c}}$ Including feeds, seeds and wastage

$\mathrm{d}$ The percentage of domestic production in total potato consumption 
Table 3 Ten most widely grown cultivars of potato in 2011 (MAFF 2015)

\begin{tabular}{|c|c|c|c|c|}
\hline \multirow[t]{2}{*}{ Main use and name } & \multirow[t]{2}{*}{ Released } & \multirow[t]{2}{*}{ Starch $(\%)$} & \multicolumn{2}{|l|}{ Japan total } \\
\hline & & & Area (ha) & Share $(\%)$ \\
\hline \multicolumn{5}{|l|}{ Table potato } \\
\hline Irish Cobbler & $1908^{\mathrm{a}}$ & 15.0 & 19,477 & 22.3 \\
\hline May Queen & $1912^{\mathrm{b}}$ & 14.6 & 9992 & 11.4 \\
\hline Nishiyutaka & 1978 & 12.8 & 5888 & 6.7 \\
\hline Kitaakari & 1987 & 17.1 & 3435 & 3.9 \\
\hline Dejima & 1971 & 15.0 & 2221 & 2.5 \\
\hline \multicolumn{5}{|c|}{ Crisp and French fry potato } \\
\hline Sayaka & 1995 & 15.1 & 1605 & 1.8 \\
\hline Toyoshiro & 1976 & 16.3 & 9497 & 10.9 \\
\hline Snowden & $2000^{\mathrm{c}}$ & 14.5 & 1952 & 2.2 \\
\hline Hokkaikogane & 1981 & 16.0 & 1885 & 2.2 \\
\hline Kitahime & 2001 & 16.0 & 1392 & 1.6 \\
\hline \multicolumn{5}{|l|}{ Starch potato } \\
\hline Konafubuki & 1981 & 22.7 & 16,285 & 18.6 \\
\hline Total & & & 87,403 & 84.2 \\
\hline
\end{tabular}

${ }^{\mathrm{a}}$ Bred in the USA in 1876

${ }^{\mathrm{b}}$ Bred in the UK around 1900

${ }^{\mathrm{c}}$ Bred in the USA in 1990

\section{Material and Methods}

For the comparison of potential yield with actual yield, the crop growth model LINTUL-POTATO-DSS (Haverkort et al. 2015) was used. Potential yields are the yields that can be calculated assuming that there are no abiotic limitations-water and nutrients - to the growth and there are no biotic factors - weeds, pests and diseases - that reduce growth. The model assumes that the sprout growth rate is $0.7 \mathrm{~mm}\left(\mathrm{~d}^{\circ} \mathrm{C}\right)^{-1}$ and that the crop needs $650 \mathrm{~d}^{\circ} \mathrm{C}$ from emergence to reach full ground cover. The radiation use efficiency (RUE) in LINTUL-POTATO-DSS is $1.25 \mathrm{~g}$ dry matter per MJ intercepted radiation or $2.5 \mathrm{~g}$ dry matter per MJ intercepted photosynthetically active radiation (PAR). RUE is dependent on temperature. It linearly increases from 0 to 1.25 from 3 to $15{ }^{\circ} \mathrm{C}$, stays at 1.25 from 15 to $20{ }^{\circ} \mathrm{C}$, and linearly decreases to 0 from 20 to $28{ }^{\circ} \mathrm{C}$. The length of the crop growth cycle exactly matches that of the length of the growing season; when the crop is dead, $75 \%$ of all dry matter produced during the growing season is assumed to be allocated to the tubers (the harvest index $(\mathrm{HI})=0.75$ ) and $25 \%$ to the foliage which is at its maximum at mid-season. The model also has routines for tuber dry matter concentration and tuber size, but in the present study, the dry matter concentration was fixed at 0.20 for all varieties and all regions and the tuber size is not discussed because no data were used on tuber quality characteristics. The model is also able to calculate water-limited yields' so-called 
"attainable" yield under rain-fed conditions. Since in all prefectures and in the case of Hokkaido in all districts precipitation exceeded evapotranspiration (ETP), this routine was not activated in any model calculation.

For the calculations, we used monthly averages of minimum and maximum day temperatures and of daily solar radiation and monthly total amounts of rainfall and ETP. The data were long-term, 10-year averages, coinciding with the length of period for which the yield data were obtained. Data per prefecture came from the MeteoCrop DB (2015) database of the National Meteorological Institute that uses data based on meteorological stations and the AMeDAS (2015) system: AMeDAS (Automated Meteorological Data Acquisition System), commonly known in Japan as "AMeDASu", is a high-resolution surface observation network developed by the Japan Meteorological Agency (JMA) used for gathering regional weather data and verifying forecast performance. The system began operating on November 1, 1974, and currently comprises 1300 stations throughout Japan with an average separation of $17 \mathrm{~km}$ (AMeDAS 2015, literal citation). In this study, data of AMeDAS was used to analyse the wide range of Japan. This database could not be used for trends of solar radiation in time as over the last 20 years, the system employed to calculate solar radiation from hours sunshine per day was changed three times (Dr. Hiroyuki Shiga, personal communication). Therefore, trends of solar radiation in time are discussed only for sites where meteorological stations exist and solar radiation was actually measured: Abashiri, Hakodate and Obihiro at Hokkaido.

Table 4 shows the weather data input for the model. Since LINTUL-POTATODSS calculates yields on a daily base, daily weather data were calculated from monthly average meteorological data. The monthly mean was assumed to be the value on the 15th of each month, and the daily weather was calculated through interpolation. Table 4 shows examples of the single summer crop in Abashiri at northern Hokkaido, of the double cropping area of Honshu at Nagasaki and of the winter crop near Naha at Okinawa. The weather data in italic figures indicate the approximate months of the cropping seasons from planting to harvest.

The annual potato cultivation area and its yield data were collected from the national statistical database of which we only used data for 10 years between 2004 and 2013 because using longer time series increases the risks of a bias by trends such as the use of plastic mulch, improved crop protection or the appearance of potato cyst nematodes and common scab (Streptomyces scabies, $S$. turgidiscabies and $S$. acidiscabies). The planting and harvest dates were from NARO (2010) for the prefectures and from the Hokkaido Government (2015) for the ten districts of Hokkaido.

For analysis of correlation, the Pearson correlation coefficient $(r)$ is used.

\section{Results and Discussion}

\section{Results of the 47 Prefectures}

The name and the number of each prefecture are shown in Fig. 1 and Table 5. Per prefecture, the average dates of planting and harvesting by the growers are shown in Table 5, both of the major spring and of the minor autumn crops. The average day and 


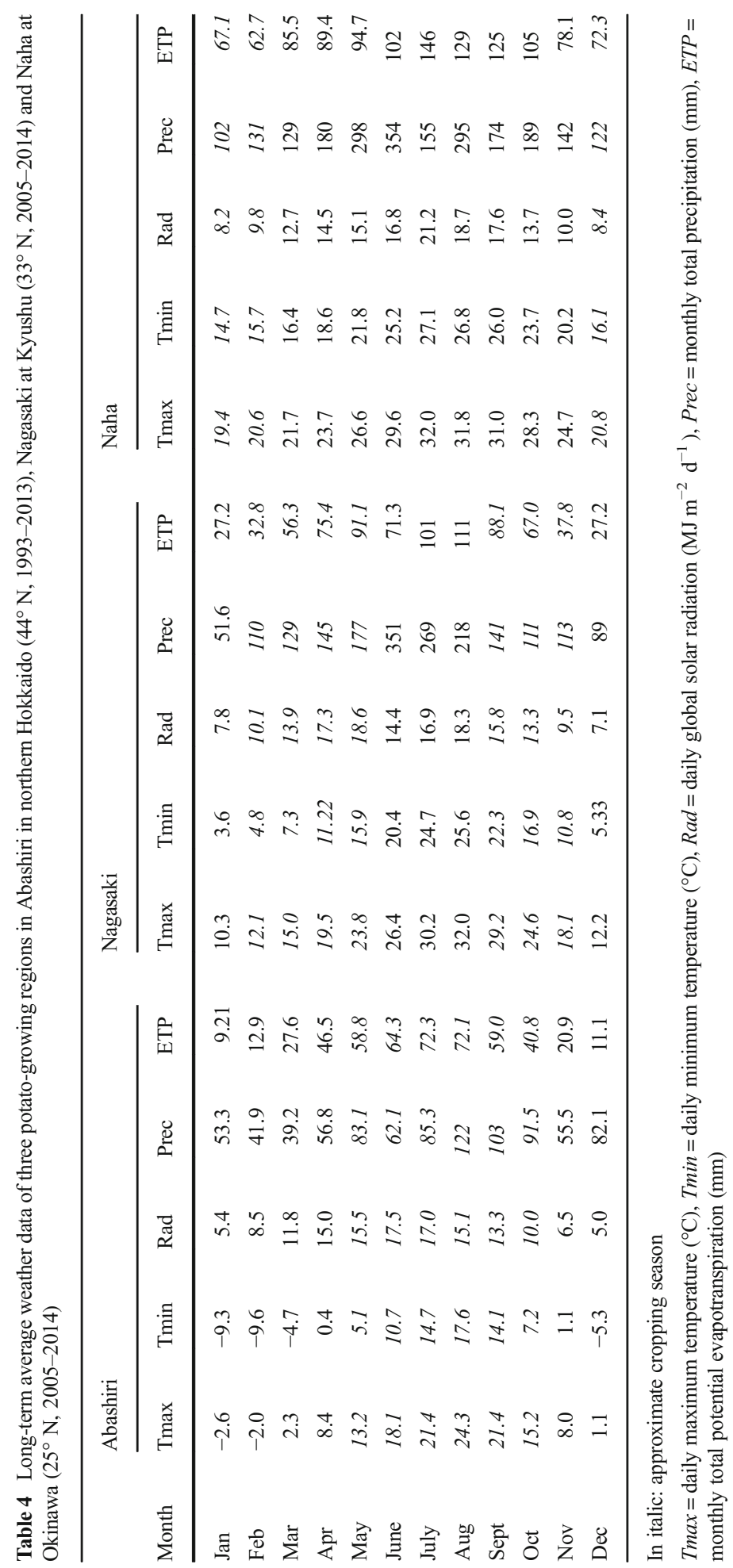


Table 5 Prefecture names, number of geographical and cropping season details for 2004-2013 average data

\begin{tabular}{|c|c|c|c|c|c|c|c|c|c|c|c|c|c|c|}
\hline \multirow[t]{2}{*}{ Prefecture } & \multirow[t]{2}{*}{$\mathrm{Nr}$} & \multicolumn{2}{|c|}{ Spring } & \multicolumn{2}{|c|}{ Autumn } & \multirow[t]{2}{*}{ Lat } & \multirow[t]{2}{*}{ Lon } & \multirow[t]{2}{*}{ Alt } & \multicolumn{2}{|c|}{ Spring } & \multicolumn{2}{|c|}{ Autumn } & \multicolumn{2}{|c|}{ Area (ha) } \\
\hline & & Pla & Har & $\mathrm{Pla}$ & Har & & & & Tav & Rav & Tav & Rav & Spring & Autumn \\
\hline Hokkaido & 1 & 133 & 263 & & & 43.5 & 142.5 & 106 & 17.2 & 16.0 & & & 54,240 & 0 \\
\hline Aomori & 2 & 110 & 242 & & & 40.8 & 140.8 & 3 & 18.4 & 17.2 & & & 1101 & 0 \\
\hline Iwate & 3 & 105 & 248 & & & 39.7 & 141.2 & 155 & 19.0 & 16.1 & & & 459 & 0 \\
\hline Miyagi & 4 & 95 & 181 & & & 38.3 & 140.9 & 38 & 15.3 & 16.8 & & & 625 & 0 \\
\hline Akita & 5 & 100 & 211 & & & 39.7 & 140.1 & 9 & 17.7 & 16.7 & & & 718 & 0 \\
\hline Yamagata & 6 & 98 & 211 & & & 38.3 & 140.3 & 153 & 18.1 & 16.9 & & & 273 & 0 \\
\hline Fukushima & 7 & 74 & 206 & & & 37.8 & 140.5 & 67 & 16.5 & 16.0 & & & 1381 & 0 \\
\hline Ibaraki & 8 & 67 & 171 & & & 36.4 & 140.5 & 29 & 13.8 & 16.5 & & & 1521 & 6 \\
\hline Tochigi & 9 & 77 & 181 & & & 36.5 & 139.9 & 119 & 16.0 & 16.1 & & & 588 & 4 \\
\hline Gunma & 10 & 56 & 161 & & & 36.4 & 139.1 & 112 & 13.4 & 16.9 & & & 464 & 2 \\
\hline Saitama & 11 & 67 & 176 & 246 & 344 & 35.9 & 139.6 & 8 & 15.7 & 16.2 & 16.4 & 11.1 & 772 & 12 \\
\hline Chiba & 12 & 56 & 156 & & & 35.6 & 140.1 & 16 & 14.1 & 15.7 & & & 1420 & 0 \\
\hline Tokyo & 13 & 67 & 171 & 232 & 337 & 35.7 & 139.8 & 6 & 16.4 & 16.1 & 19.8 & 11.5 & 289 & 11 \\
\hline Kanagawa & 14 & 67 & 186 & 230 & 327 & 35.4 & 139.7 & 39 & 16.9 & 16.2 & 20.4 & 12.7 & 451 & 36 \\
\hline Niigata & 15 & 115 & 206 & & & 37.9 & 139.0 & 2 & 20.1 & 17.7 & & & 803 & 2 \\
\hline Toyama & 16 & 105 & 209 & & & 36.7 & 137.2 & 9 & 20.1 & 17.1 & & & 130 & 2 \\
\hline Ishikawa & 17 & 95 & 211 & & & 36.6 & 136.6 & 6 & 19.6 & 17.6 & & & 306 & 3 \\
\hline Fukui & 18 & 72 & 191 & & & 36.1 & 136.2 & 9 & 16.5 & 16.1 & & & 356 & 19 \\
\hline Yamanashi & 19 & 84 & 232 & & & 35.7 & 138.6 & 273 & 20.7 & 17.8 & & & 324 & 3 \\
\hline Nagano & 20 & 84 & 232 & & & 36.7 & 138.2 & 418 & 18.5 & 17.9 & & & 1200 & 0 \\
\hline Gifu & 21 & 72 & 181 & & & 35.4 & 136.8 & 13 & 17.3 & 17.5 & & & 286 & 15 \\
\hline Shizuoka & 22 & 72 & 196 & 237 & 329 & 35.0 & 138.4 & 14 & 12.4 & 16.1 & 16.1 & 11.6 & 682 & 46 \\
\hline Aichi & 23 & 46 & 166 & 232 & 347 & 35.2 & 137.0 & 51 & 14.2 & 16.7 & 18.5 & 12.4 & 347 & 60 \\
\hline Mie & 24 & 56 & 191 & & & 34.7 & 136.5 & 2 & 16.5 & 11.5 & & & 197 & 21 \\
\hline Shiga & 25 & 72 & 181 & & & 35.0 & 135.9 & 89 & 11.3 & 16.1 & & & 171 & 23 \\
\hline Kyoto & 26 & 72 & 176 & & & 35.0 & 135.7 & 41 & 16.7 & 16.2 & & & 228 & 3 \\
\hline Osaka & 27 & 56 & 166 & & & 34.7 & 135.5 & 23 & 15.5 & 16.7 & & & 85 & 9 \\
\hline Hyogo & 28 & 49 & 181 & & & 34.7 & 135.2 & 5 & 15.9 & 16.3 & & & 374 & 7 \\
\hline Nara & 29 & 64 & 171 & & & 34.7 & 135.8 & 104 & 14.7 & 16.2 & & & 177 & 4 \\
\hline Wakayama & 30 & 59 & 150 & 246 & 334 & 34.2 & 135.2 & 14 & 14.4 & 17.0 & 19.3 & 12.5 & 77 & 6 \\
\hline Tottori & 31 & 74 & 171 & & & 35.5 & 134.2 & 7 & 15.4 & 16.8 & & & 186 & 3 \\
\hline Shimane & 32 & 74 & 171 & 251 & 334 & 35.5 & 133.1 & 17 & 15.3 & 16.9 & 17.1 & 11.2 & 179 & 16 \\
\hline Okayama & 33 & 64 & 171 & 248 & 347 & 34.7 & 133.9 & 3 & 16.2 & 17.2 & 17.2 & 11.9 & 254 & 74 \\
\hline Hiroshima & 34 & 74 & 161 & 248 & 339 & 34.4 & 132.4 & 29 & 16.1 & 17.8 & 18.1 & 12.5 & 395 & 200 \\
\hline Yamaguchi & 35 & 60 & 181 & 251 & 344 & 34.2 & 131.5 & 17 & 16.0 & 16.3 & 16.3 & 11.6 & 183 & 56 \\
\hline Tokushima & 36 & 41 & 161 & 253 & 339 & 34.1 & 134.6 & 2 & 14.0 & 16.2 & 18.2 & 11.6 & 138 & 12 \\
\hline Kagawa & 37 & 51 & 176 & 248 & 347 & 34.3 & 134.1 & 9 & 9.1 & 14.9 & 11.9 & 9.2 & 86 & 30 \\
\hline Ehime & 38 & 41 & 156 & 242 & 334 & 33.8 & 132.8 & 32 & 13.6 & 16.1 & 19.5 & 12.7 & 253 & 85 \\
\hline Kochi & 39 & 62 & 181 & & & 33.6 & 133.5 & 1 & 17.5 & 16.7 & & & 113 & 37 \\
\hline Fukuoka & 40 & 56 & 156 & 242 & 305 & 33.6 & 130.4 & 3 & 15.4 & 16.7 & 22.6 & 14.0 & 333 & 42 \\
\hline Saga & 41 & 36 & 152 & 253 & 359 & 33.2 & 130.3 & 4 & 13.5 & 15.7 & 15.9 & 11.6 & 137 & 46 \\
\hline
\end{tabular}


Table 5 (continued)

\begin{tabular}{|c|c|c|c|c|c|c|c|c|c|c|c|c|c|c|}
\hline \multirow[t]{2}{*}{ Prefecture } & \multirow[t]{2}{*}{$\mathrm{Nr}$} & \multicolumn{2}{|c|}{ Spring } & \multicolumn{2}{|c|}{ Autumn } & \multirow[t]{2}{*}{ Lat } & \multirow[t]{2}{*}{ Lon } & \multirow[t]{2}{*}{ Alt } & \multicolumn{2}{|c|}{ Spring } & \multicolumn{2}{|c|}{ Autumn } & \multicolumn{2}{|c|}{ Area (ha) } \\
\hline & & $\mathrm{Pla}$ & Har & Pla & Har & & & & Tav & Rav & Tav & Rav & Spring & Autumn \\
\hline Nagasaki & 42 & 62 & 156 & 248 & 339 & 32.7 & 129.9 & 27 & 15.7 & 16.7 & 19.2 & 12.4 & 2988 & 1114 \\
\hline Kumamoto & 43 & -6 & 160 & 237 & 344 & 32.8 & 130.7 & 38 & 12.5 & 14.0 & 19.2 & 13.0 & 575 & 71 \\
\hline Oita & 44 & 41 & 161 & 242 & 354 & 33.2 & 131.6 & 5 & 14.1 & 16.0 & 17.6 & 11.7 & 139 & 41 \\
\hline Miyazaki & 45 & 30 & 150 & 253 & 364 & 31.9 & 131.4 & 6 & 14.2 & 15.9 & 16.4 & 12.0 & 521 & 60 \\
\hline Kagoshima & 46 & 25 & 141 & 258 & 15 & 31.6 & 130.6 & 4 & 14.3 & 14.9 & 16.3 & 11.1 & 3751 & 584 \\
\hline Okinawa & 47 & & & 278 & 25 & 26.2 & 127.7 & 35 & & & 20.8 & 10.0 & & 139 \\
\hline
\end{tabular}

$N r=$ number (location, see Fig. 1), Pla = day of year of planting, Har = day of year of harvest, Lat $=$ latitude $^{\circ}$ $\mathrm{N}$, Lon $=$ longitude ${ }^{\circ} \mathrm{E}$, Alt $=$ altitude above sea level $(\mathrm{m})$, Tav $=$ daily average temperature $\left({ }^{\circ} \mathrm{C}\right), \operatorname{Rav}=$ average daily solar radiation $\left(\mathrm{MJ} \mathrm{m}^{-2} \mathrm{~d}^{-1}\right)$

night temperatures and the average daily solar radiation are shown between planting and harvest. The last two columns show the importance of the crop expressed as cultivation area in each season.

It is obvious that, although a spring (including a summer) crop of potato is grown in all prefectures, Kyushu with Nagasaki (2988 ha) and Kagoshima (3751 ha) and the ten districts at Hokkaido (54,240 ha) are the main centres of cultivation. At higher latitudes, notably as of $36^{\circ} \mathrm{N}$, the area of autumn crop is negligible and has not been reported in some years.

The highest actual yields (Fig. 4) are recorded in the potato-growing districts of Hokkaido (number 1), followed by Ibaraki (8), Shizuoka (22), Nagasaki (42) and Kagoshima (46). In many prefectures, the average yields are well below $15 \mathrm{t} \mathrm{ha}^{-1}$, especially between latitudes 36.7 and 33.6, with the exception of Nagano (20) and Shizuoka (22). The average actual yield of the spring crops not weighted by acreage is around $17 \mathrm{t} \mathrm{ha}^{-1}$, and the actual/potential ratio on average is 0.35 (not weighted for area). The potential yield at Kumamoto (43) is the second highest because of the long growing season, but the modest actual yield of $20 \mathrm{t} \mathrm{ha}^{-1}$ is due to the great variation in growing conditions (site and dates) here. Miyagi (4) has the lowest potential yield, $32 \mathrm{tha}^{-1}$, with the actual yield being half of this, because of the short growing season. Growers here harvest potato much earlier than in the neighbouring prefectures (Table 5) because they give priority to rice. Growers at Nagasaki (42) achieve the highest yield in southern Japan and also the highest actual/potential yield ratio. It is due to the reason that growers here apply optimal inputs and operations. Figure 4 also shows the actual and potential yield data of the autumn crops. Only in 21 out of 47 prefectures an autumn crop is planted every year. The main planting month is September, and the figure also includes the winter crop at Okinawa where the planting month is November. The average potential and actual yields of the autumn crops are substantially lower than those of the spring crops. The average actual yield of the autumn crops, not weighted by acreage, is around $12 \mathrm{tha}^{-1}$, and the actual/potential ratio on average is 0.37 , similar to the ratio in the spring season. Fukuoka (39) has the lowest actual and potential yields of the autumn crop with only a two and half months' growing season. Outside Hokkaido, Nagasaki (42) had the highest spring crop yield and also the highest yield 


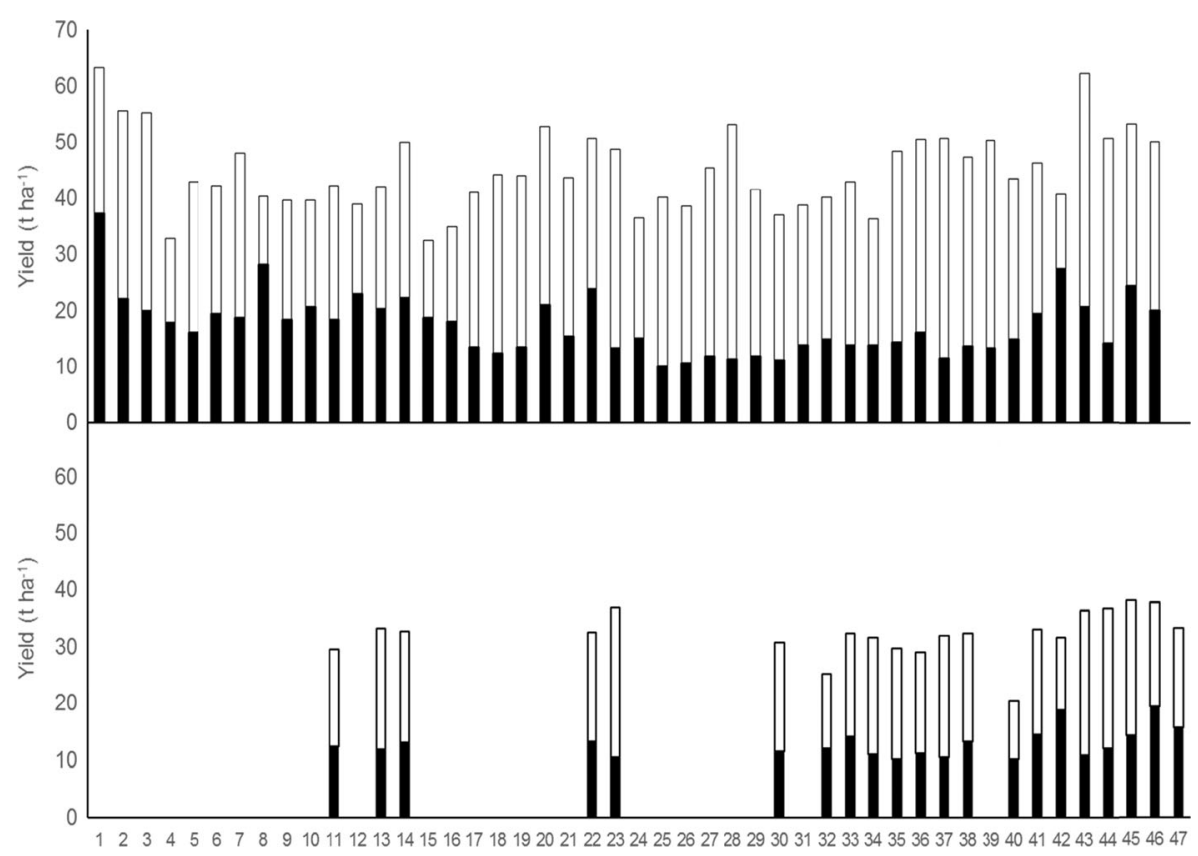

Fig. 4 Potential (open) and actual (closed) yield levels of the spring (top) and autumn (below) crops. Numbers indicate the corresponding prefecture shown in Table 5

of the autumn crop. The higher actual and potential yields of the spring crops than those of the autumn crops are caused by the higher temperatures, often too high for optimal RUE, lower solar radiation and a shorter growing season of the autumn crops. Actual and potential yields of the winter crop at Okinawa are comparable to those of the autumn crops in the other prefectures.

The relationship between actual and potential yields is shown in Fig. 5 both for the spring and the autumn crops. From the $r$ value of 0.414 , an $r^{2}$ value 0.172 was calculated. Although the relationship was significant, The $\mathrm{r} 2$ value indicates that $17 \%$

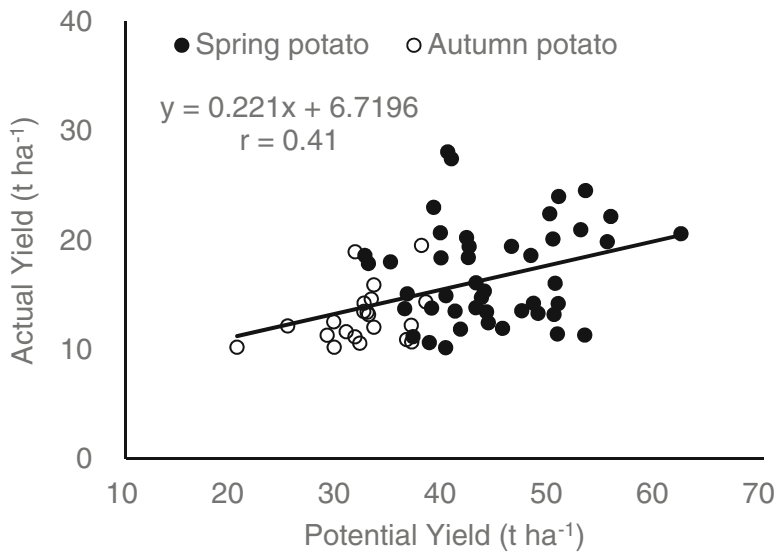

Fig. 5 Actual versus potential yields of the spring and autumn crops (Hokkaido was excluded, if included $y=0.292+4.05, r=0.50(p \leq 0.05))$ 
of the variation in actual yield is accounted for by variation in yielding ability. Potato growers in the prefectures outside Hokkaido have many reasons to give priority to the main crop rice and to harvest potato prematurely if favourable prices can be fetched for potato as a vegetable.

We hypothesized that there would be a positive correlation between latitude and actual yield as the yields in the northernmost areas of Japan are the highest. However, this is not confirmed in Fig. 6. The significant $r$ value of 0.38 is merely due to the influence of the single dot of Hokkaido. The figure shows three groups of yields: the first group is the autumn crops of low yields with a slight tendency towards lower yields at higher latitudes, partly caused by a shorter growing season going north, with an $r$ value of $-0.49(p \leq 0.05)$ (line not shown). The second group is the spring crops at the prefectures south of Hokkaido with no correlation to latitude at all with an $r$ value of 0.15 . The third group is represented by the high-yielding districts of Hokkaido which has ten main potato-growing districts, represented by one single dot in Fig. 6. The yields of these districts of Hokkaido are out of range of those of the other prefectures, indicating the reason why almost $80 \%$ of all potatoes grown in Japan is produced in this northern region; its yield levels are treated in the next section.

According to the correlation matrix in spring potato which excluded Hokkaido and Okinawa (Table 6), the planting and harvest dates are strongly correlated with latitude: the further north, crops are planted $(r=0.84)$ and harvested $(r=0.79)$ later in the season due to frost risks after emergence. The strong correlation between latitude and longitude stems from the shape of the country from Okinawa to Hokkaido in a northeast direction. The high, positive correlations of the average temperature with latitude, planting and harvest dates are somewhat unexpected. Apparently, going south, the climate allows a time slot for a rice crop and the growing season of a spring potato crop results in avoiding relatively high

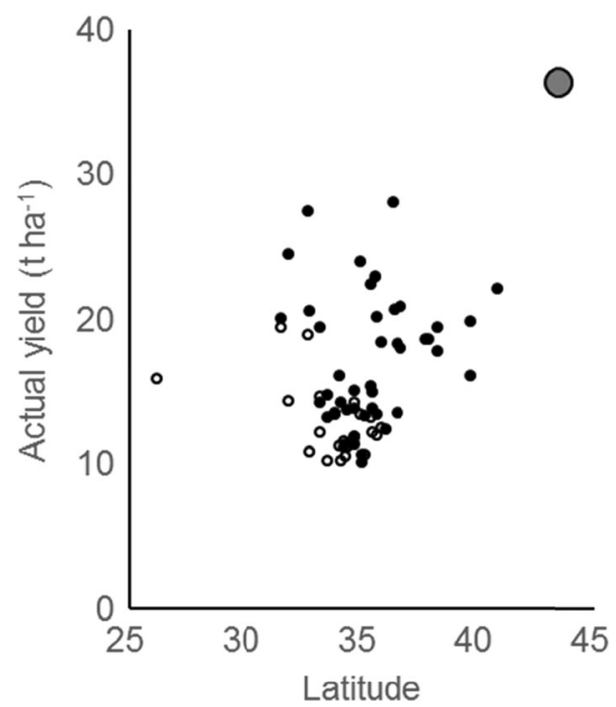

Fig. 6 Relationship between latitude and actual yield of the spring crops (open symbols) and the autumn crops (closed symbols). Hokkaido is represented by a single large dot top right. The correlation coefficient is $r=0.34$ ( $p \leq 0.05)$ in all prefectures, but if Hokkaido is excluded, it is $r=0.15$ (not significant) 
Table 6 Correlation matrix $(r \times 100)$ of spring crop data of 45 prefectures $(\mathrm{DxR}=\mathrm{GD} \times \mathrm{Rav})$

\begin{tabular}{|c|c|c|c|c|c|c|c|c|c|c|c|}
\hline & Lon & Alt & Plant & Harv & GD & Ypot & Yact & $\mathrm{A} / \mathrm{P}$ & Tav & Rav & DxR \\
\hline Latitude & 84 & 26 & 84 & 79 & 1 & -18 & 13 & 22 & 53 & 33 & 18 \\
\hline Longitude (Lon) & & 32 & 66 & 63 & 2 & -22 & 24 & 34 & 38 & 19 & 13 \\
\hline Altitude (Alt) & & & 25 & 50 & 40 & 13 & 8 & -1 & 29 & 27 & 59 \\
\hline Planting date (Plant) & & & & 77 & -25 & -44 & 2 & 25 & 69 & 53 & 2 \\
\hline Harvest date (Harv) & & & & & 43 & 11 & 6 & 0 & 68 & 26 & 59 \\
\hline Growth duration (GD) & & & & & & 79 & 6 & -35 & 5 & -35 & 86 \\
\hline Potential yield (Ypot) & & & & & & & 16 & -38 & -20 & -21 & 73 \\
\hline Actual yield (Yact) & & & & & & & & 85 & 2 & -5 & 4 \\
\hline Actual:potential yield ratio (A:P) & & & & & & & & & 12 & 5 & -35 \\
\hline $\begin{array}{l}\text { Average temperature during growing } \\
\text { season (Tav) }\end{array}$ & & & & & & & & & & 44 & 29 \\
\hline $\begin{array}{l}\text { Average daily solar radiation during } \\
\text { growing season (Rav) }\end{array}$ & & & & & & & & & & & 16 \\
\hline
\end{tabular}

Italic: significant $(p \leq 0.05)$, Okinawa and Hokkaido excluded

temperatures. At higher altitudes, the crop is harvested later which also leads to a greater value of radiation $\times$ number of growing days. Growth duration is correlated positively with potential yield but is associated with lower average daily radiation since longer seasons have more days with early spring short photoperiods. Actual yields increase with potential yields as was also shown in Fig. 5. The autumn crop shows similar but less outspoken tendencies (not shown) within general negative values for the first two rows indicative of less favourable conditions at higher latitudes. The length of the growing season is mainly determined by the later harvest date which is obvious from the $r=0.43$ but does not lead to higher yields because of the negative relation between growth duration and average daily radiation $(r=-0.35)$.

\section{Results of the Ten Potato-Growing Districts of Hokkaido}

This section focuses on the ten main potato-growing districts of Hokkaido (Fig. 1). Table 5 shows the weather data during the 5 months of the growing season from May to September, averaged over the 21-year period. The coolest district of Hokkaido is Teshikaga, with $14.3{ }^{\circ} \mathrm{C}$ similar to Nakashibetsu, and the warmest district was Esashi being $4{ }^{\circ} \mathrm{C}$ warmer. Teshikaga and Nakashibetsu also have the lowest amount of solar radiation, around 12.7 $\mathrm{MJ} \mathrm{m}^{-1} \mathrm{~d}^{-1}$, whereas some districts such as Abashiri have an almost 25\% higher solar radiation level. Precipitation in all districts is higher than ETP.

The location, season, planting and harvest dates were also recorded (not shown), and the length of the growing season that can be derived from it is shown (GD). GD varied from 119 to 139 days. The total area cultivated with potato in the ten districts decreased from 12,679 to 10,781 ha over the 21-year period. In some districts, the area remained stable while in others, it declined strongly depending on the agricultural system of each 
district. For example, in Nakashibetsu, with dairy farming, potato production decreased in favour of maize for feed.

The actual yields of the ten districts (Table 8) in Hokkaido on average have declined from 35.2 to $32.2 \mathrm{t} \mathrm{ha}^{-1}$, a $8.2 \%$ decline whereas the current potential yield of $55.9 \mathrm{t} \mathrm{ha}^{-1}$ has not noticeably been altered over the 21 -year period. The main reason for the yield decline is the change of variety. With the replacement of the low dry matter starch variety Benimaru (about $16 \%$ of starch concentration) with the high dry matter starch variety Konafubuki (about 22\%), starch yields went up but the fresh yields went down. In addition, cultivation of varieties suitable for processing into crisps and fries has increased considerably despite their lower yields (but a higher price) compared to starch varieties. Some districts in northern Hokkaido suffer from potato cyst nematodes which reduce yields, and resistant varieties such as Early Starch and Astarte have lower yields than Konafubuki. In addition, some southern districts harvest earlier for market reasons.

The potential yields are highest in Abashiri because of its long growing season and high radiation and lowest in Teshikaga because of its low radiation level (Table 7). The column A/P shows that on average, $62 \%$ of the potential yield is actually obtained but that this percentage varies from Hakodate with $52 \%$ to Abashiri with $68 \%$.

The trends in time of actual yield, potential yield and $\mathrm{A} / \mathrm{P}$ ratio in Abashiri are shown in Fig. 7. No significant effect of year on the potential yield was found but a significant decline in actual yield of $0.48 \mathrm{tha}^{-1}$ per year. In Obihiro (figure not shown), the other main centre of production, yields declined by $0.28 \mathrm{t} \mathrm{ha}^{-1}$ per year because of the gradual replacement of a starch variety by a crisp variety.

Table 9 shows the correlation matrix of the ten districts at Hokkaido. The further north, the later are the harvest dates, the higher the actual yields and the actual/potential yield ratios and the lower the average daily temperatures. The lower temperatures

Table 7 Average May-September weather data from AMeDAS of the 1993-2013 period in the selected Hokkaido districts and trends in average potato area of all districts over this period

\begin{tabular}{lrrllllllr}
\hline District & Nr & Tav & Rav & Prec & ETP & Prec-ETP & GD & A1 & A2 \\
\hline Abashiri & 1 & 15.6 & $15.6 / 16.9$ & 2.84 & 2.09 & 0.74 & 139 & 2993 & 3017 \\
Biei & 2 & 16.6 & 14.9 & 3.58 & 1.89 & 1.69 & 128 & 1433 & 1197 \\
Date & 3 & 17.2 & 14.4 & 3.40 & 1.74 & 1.66 & 119 & 137 & 81 \\
Eniwashimamatsu & 4 & 16.8 & 14.1 & 3.79 & 1.85 & 1.93 & 128 & 179 & 196 \\
Esashi & 5 & 18.3 & 15.3 & 4.08 & 2.11 & 1.98 & 131 & 127 & 94 \\
Hakodate & 6 & 18.0 & $15.3 / 16.2$ & 3.89 & 2.25 & 1.64 & 127 & 921 & 481 \\
Kutchan & 7 & 16.9 & 15.5 & 3.39 & 2.08 & 1.31 & 122 & 1290 & 1297 \\
Nakashibetsu & 8 & 14.6 & 12.6 & 4.25 & 1.76 & 2.49 & 141 & 1210 & 488 \\
Obihiro & 9 & 17.0 & $13.8 / 15.5$ & 3.62 & 2.73 & 0.89 & 136 & 3730 & 3480 \\
Teshikaga & 10 & 14.3 & 12.8 & 3.85 & 1.66 & 2.19 & 130 & 659 & 450 \\
Hokkaido average 21 years & & 16.5 & 14.4 & 3.67 & 2.02 & 1.65 & & & \\
\hline
\end{tabular}

In italic: radiation data actually measured at the site, not from the AMeDAS database

$N r=$ number of district (Fig. 1), Tav = average daily temperature $\left({ }^{\circ} \mathrm{C}\right), \operatorname{Rav}=$ average radiation $\left(\mathrm{MJ} \mathrm{m}^{-2} \mathrm{~d}^{-1}\right)$, Prec $=$ precipitation $\left(\mathrm{mm} \mathrm{d}^{-1}\right), E T P=$ evapotranspiration $\left(\mathrm{mm} \mathrm{day}^{-1}\right), G D$ growth duration $(\mathrm{d}), A l=$ average potato area (ha) 1993-1995, A2 average potato area (ha) 2011-2013 


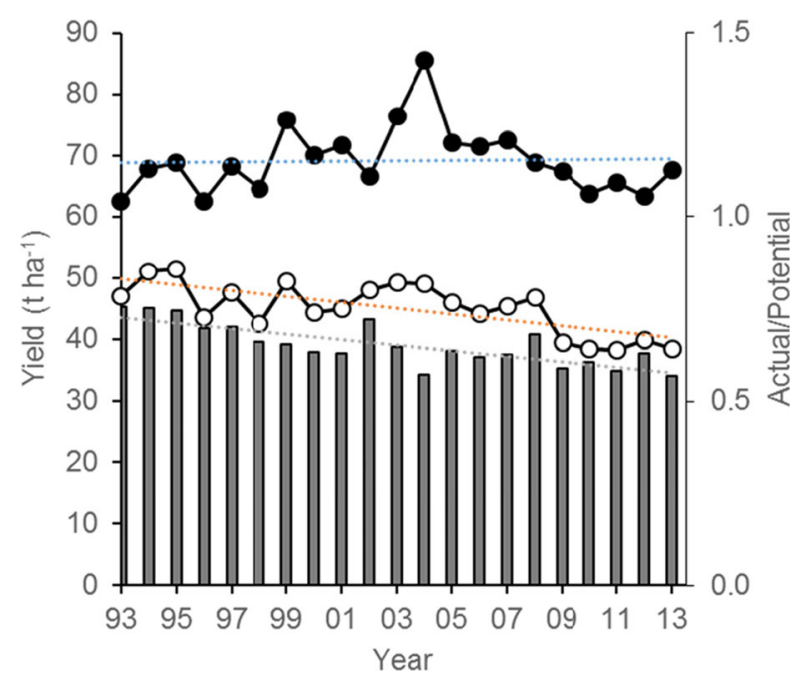

Fig. 7 Actual (open symbols) yields, potential yields (closed symbols) and their ratios (bars) over a 21-year period at Abashiri. For potential yields, $y=0.025 x+68.9, r=0.03$; for actual yield, $y=-0.48 x+50.3, r=0.71$; for the ratio, $y=-0.0 .75 x+0.73, r=0.80$

significantly negatively influence the planting and harvest dates. The earlier harvests in Date and Hakodate are not due to a shorter growing season but mainly growers follow the market. The actual/potential yield ratio declines with higher average temperatures during the growing season. This was not due to high temperatures having a negative effect on RUE but because going south, the potential yield is not much affected by latitude $(r=0.29)$ whereas the actual is $(r=0.83)$, as discussed above, for economic reasons. At Hokkaido, the relationship between actual yield $(y)$ and potential yield $(x)$ is $y=0.52 x+6.21(r=0.55)$; for the 46 prefectures without Hokkaido (Fig. 5), it was $y=$ $0.22 x+6.72(r=0.41)$. The slopes 0.52 versus 0.22 are indicative of the proportion of the potential that is actually achieved: much more at Hokkaido than in the rest of the country.

The values of columns A in Table 8 apply when the current average planting dates are inserted. If the earliest possible planting date and latest possible harvest date are inserted, the potential yield on average moves from 55.9 to $68.7 \mathrm{t} \mathrm{ha}^{-1}$, a $25 \%$ increase. The actual proportion of potential then declines to 0.50 with large variation among sites. In the main potato region of Abashiri, extending the growing season maximally leads to a yield increase from 66.1 to $78.8 \mathrm{t} \mathrm{ha}^{-1}$ equivalent to $16 \%$ increase. Exploring the repercussions of the climate change, an increase in temperature of $2{ }^{\circ} \mathrm{C}$ leads to a decrease of the potential yield on average of all districts from the current 55.9 to $53.1 \mathrm{t} \mathrm{ha}^{-1}$. Especially, Esashi and Hakodate that already now have high summer average temperatures of over $18{ }^{\circ} \mathrm{C}$ will suffer many more days with average temperatures above $20^{\circ} \mathrm{C}$ with negative impact on radiation use efficiency. The coolest district Teshikaga, however, with average temperature of only $14.3^{\circ} \mathrm{C}$ benefits from higher temperatures with a potential yield increase from 48 to $52 \mathrm{t} \mathrm{ha}^{-1}$. Extending the growing season by 2 weeks, one in spring and one in autumn, leads to a potential yield increase average for all districts from 53.1 to $59.9 \mathrm{t} \mathrm{ha}^{-1}$. Especially, Date and Kutchan that have relatively short seasons (Table 7) benefit more than average. With an estimated yield increase of $28 \%$ in potato associated with $\mathrm{CO}_{2}$ concentration of 
Table 8 Yield levels $\left(\mathrm{t} \mathrm{ha}^{-1}\right)$ of potato in the ten districts of Hokkaido

\begin{tabular}{|c|c|c|c|c|c|c|c|c|}
\hline \multirow[t]{2}{*}{ District } & \multicolumn{2}{|l|}{ Actual yield } & \multirow[t]{2}{*}{$P Y^{a}$} & \multirow[t]{2}{*}{$\mathrm{A} / \mathrm{P}^{\mathrm{a}}$} & \multirow[t]{2}{*}{$\mathrm{PY}^{\mathrm{b}}$} & \multirow[t]{2}{*}{$\mathrm{PY}^{\mathrm{c}}$} & \multirow[t]{2}{*}{$P Y^{d}$} & \multirow[t]{2}{*}{$P Y^{e}$} \\
\hline & 1993-1995 & 2011-2013 & & & & & & \\
\hline Abashiri & 49.9 & 38.9 & 66.1 & 0.68 & 78.8 & 66.3 & 73.9 & 94.6 \\
\hline Biei & 36.7 & 33.4 & 60.6 & 0.60 & 70.6 & 55.9 & 62.9 & 80.5 \\
\hline Date & 32.4 & 29.9 & 49.5 & 0.64 & 64.5 & 44.5 & 51.9 & 66.5 \\
\hline Eniwashimamatsu & 33.3 & 37.5 & 54.5 & 0.63 & 71.1 & 50.7 & 57.6 & 73.8 \\
\hline Esashi & 28.6 & 23.8 & 57.9 & 0.50 & 70.0 & 48.2 & 56.0 & 71.7 \\
\hline Hakodate & 28.1 & 28.8 & 54.6 & 0.52 & 76.3 & 49.8 & 56.1 & 71.9 \\
\hline Kutchan & 35.4 & 31.0 & 57.8 & 0.60 & 68.4 & 53.0 & 60.4 & 77.3 \\
\hline Nakashibetsu & 32.5 & 32.6 & 51.7 & 0.61 & 59.3 & 55.7 & 61.2 & 78.3 \\
\hline Obihiro & 38.5 & 33.6 & 58.1 & 0.63 & 70.1 & 54.4 & 61.2 & 78.3 \\
\hline Teshikaga & 36.8 & 33.7 & 48.1 & 0.77 & 58.2 & 52.1 & 57.5 & 73.6 \\
\hline Hokkaido average & 35.2 & 32.3 & 55.9 & 0.62 & 68.7 & 53.1 & 59.9 & 76.6 \\
\hline
\end{tabular}

$P Y=$ potential yield, $A / P=$ actual/potential yield, 1993-2013 average

${ }^{a}$ Potential yield (PY) based on average planting and harvest dates per district

${ }^{\mathrm{b}}$ Potential yield based on earliest possible planting and latest possible harvest

${ }^{\mathrm{c}}$ Potential yields of average planting and harvest days, added $2{ }^{\circ} \mathrm{C}$ to Tmax and Tmin

${ }^{\mathrm{d}} \mathrm{PY}$ as in $\mathrm{c}$ but planting 1 week earlier and harvest 1 week later

${ }^{\mathrm{e}} \mathrm{PY}$ as d but RUE $=1.60 \mathrm{~g} \mathrm{MJ}-1$ (that is $28 \%$ higher than current) as predicted for 2050

the air of $550 \mathrm{ppm}$ compared to the $380 \mathrm{ppm}$ of the year 2000 (Jaggard et al. 2010), the potential yield at Abashiri approaches $95 \mathrm{t} \mathrm{ha}^{-1}$.

Table 9 Correlation matrix $(r \times 100)$ of the districts of Hokkaido $(\mathrm{DxR}=\mathrm{GD} \times \mathrm{Rav})$

\begin{tabular}{|c|c|c|c|c|c|c|c|c|c|c|c|}
\hline & Lon & Alt & Plant & Harv & GD & Ypot & Yact & $\mathrm{A} / \mathrm{P}$ & Tav & Rav & DxR \\
\hline Latitude & 84 & 43 & 61 & 71 & 49 & 29 & 83 & 71 & -70 & -42 & -15 \\
\hline Longitude (Lon) & & 18 & 58 & 83 & 75 & 6 & 60 & 66 & -90 & -72 & -31 \\
\hline Altitude (Alt) & & & 55 & 27 & 21 & 37 & 26 & 31 & -5 & -9 & -23 \\
\hline Planting date (Plant) & & & & 84 & 23 & -18 & 26 & 50 & -48 & -63 & -55 \\
\hline Harvest date (Harv) & & & & & 72 & 9 & 39 & 41 & -65 & -69 & 31 \\
\hline Growth duration (GD) & & & & & & 40 & 37 & 10 & -55 & -43 & 16 \\
\hline Potential yield (Ypot) & & & & & & & 55 & -23 & 24 & 57 & 88 \\
\hline Actual yield (Yact) & & & & & & & & 68 & -45 & -3 & 23 \\
\hline Actual:potential yield ratio (A:P) & & & & & & & & & -73 & -55 & -51 \\
\hline $\begin{array}{l}\text { Average temperature during growing } \\
\text { season (Tav) }\end{array}$ & & & & & & & & & & 77 & 49 \\
\hline $\begin{array}{l}\text { Average daily solar radiation during } \\
\text { growing season (Rav) }\end{array}$ & & & & & & & & & & & 83 \\
\hline
\end{tabular}

Italic: significant $(p \leq 0.05)$ 
These findings are much in line with those of Haverkort et al. (2013) who predicted similar yield increases in the partly rain-fed and irrigated summer crops in South Africa. This conclusion, however, deviates from a scientific report on the impact of global warming on agricultural productivity in Hokkaido (Agricultural Experimental Station 2011). That report using an IPPC scenario concludes that potato yields will decline by $15 \%$ in 2035 , not because of a $1.8^{\circ} \mathrm{C}$ temperature increase but due to a $15 \%$ decrease in solar radiation. "An extended growing season, with an advanced planting date will not compensate for this decrease in yield". The report did not, however, touch upon the favourable effect of the increase of $\mathrm{CO}_{2}$ on crop production as we did in our calculation. Furthermore, there was no reduction of incident solar radiation over the last 21 years when we analysed the AMeDAS data, being indicative of no decline in the future. So, our findings do not corroborate the lower yields associated with a lower radiation level at Hokkaido (Agricultural Experimental Station 2011) but show that the extended growing season does compensate for a yield reduction caused by a higher temperature and that the fertilizing effect of $\mathrm{CO}_{2}$ leads to an expected yield increase of about $28 \%$ compared to current yields by 2050 (Table 9).

To benchmark the Japanese potato production and yielding ability against some other systems, it is essential to use the same calculation method. Therefore, recent studies which applied the LINTUL-POTATO-DSS model (Haverkort et al. 2015) were analysed and compared. Where certain data such as the length of the growing season is not mentioned in

Table 10 Benchmarking Japan against some selected potato production regions where the same model (LINTUL-POTATO-DSS) was used

\begin{tabular}{lcccccccc}
\hline Production site & Lat & Long & Tav & Rav & GD & Ypot & Yact & A/P \\
\hline Abashiri, Japan $^{\mathrm{a}}$ & $44^{\circ} \mathrm{N}$ & $144^{\circ} \mathrm{E}$ & 14.2 & 14.7 & 144 & 65 & 45 & 0.68 \\
Nagasaki, Japan $^{\mathrm{a}}$ & $33^{\circ} \mathrm{N}$ & $130^{\circ} \mathrm{E}$ & 13.6 & 15.0 & 92 & 44 & 28 & 0.68 \\
Okinawa, Japan $^{\mathrm{a}}$ & $26^{\circ} \mathrm{N}$ & $127^{\circ} \mathrm{E}$ & 20.8 & 11.5 & 110 & 32 & 15 & 0.48 \\
Flevoland, the Netherlands $^{\mathrm{b}}$ & $52^{\circ} \mathrm{N}$ & $5^{\circ} \mathrm{E}$ & 14.6 & 15.4 & 163 & 95 & 63 & 0.66 \\
Drenthe, Netherlands $^{\mathrm{b}}$ & $52^{\circ} \mathrm{N}$ & $5^{\circ} \mathrm{E}$ & 14.8 & 15.6 & 172 & 99 & 47 & 0.47 \\
Maine, USA $^{\mathrm{b}}$ & $46^{\circ} \mathrm{N}$ & $67^{\circ} \mathrm{W}$ & 15.9 & 19.2 & 110 & 76 & 36 & 0.47 \\
Washington, USA $^{\mathrm{b}}$ & $47^{\circ} \mathrm{N}$ & $117^{\circ} \mathrm{W}$ & 22.5 & 25.6 & 170 & 125 & 76 & 0.61 \\
Osorno, Chile $^{\mathrm{c}}$ & $38^{\circ} \mathrm{S}$ & $72^{\circ} \mathrm{W}$ & 14.1 & 22.0 & 148 & 81 & 33 & 0.41 \\
Highveld, South Africa $^{\mathrm{d}}$ & $29^{\circ} \mathrm{S}$ & $28^{\circ} \mathrm{E}$ & 19.5 & 25.2 & 120 & 91 & 50 & 0.55 \\
Nyakosoba, Lesotho $^{\mathrm{e}}$ & $30^{\circ} \mathrm{S}$ & $28^{\circ} \mathrm{E}$ & 17.0 & 19.1 & 120 & 68 & $32^{*}$ & 0.47 \\
Country wide, Zimbabwe $^{\mathrm{f}}$ & $18^{\circ} \mathrm{S}$ & $31^{\circ} \mathrm{E}$ & 15.8 & 21.5 & 126 & 88 & 28 & 0.32 \\
\hline
\end{tabular}

Lat $=$ latitude $\left({ }^{\circ}\right)$, Long $=$ longitude $\left({ }^{\circ}\right)$, Tav = average daily temperature during the growing season $\left({ }^{\circ} \mathrm{C}\right)$, $R a v=$ Average daily radiation $\left(\mathrm{MJ} \mathrm{m}^{-2}\right), P o t=$ potential yield $\left(\mathrm{t} \mathrm{ha}^{-1}\right), A c t=$ actual yield $\left(\mathrm{t} \mathrm{ha}^{-1}\right)$, $A / P=$ ratio of actual potential yield

${ }^{a}$ Figure 4 and Table 7

${ }^{\mathrm{b}}$ Haverkort, A J. unpublished, the calculations were done for the present publication

${ }^{\mathrm{c}}$ Haverkort et al. (2014)

${ }^{\mathrm{d}}$ Haverkort et al. (2013)

e Molahlehi et al. (2013),*

${ }^{\mathrm{f}}$ Svubure et al. (2015) 
the publication cited, the original data on which the publication was based, were consulted. The results are shown in Table 10. Although the average temperature and solar radiation during the growing season in Hokkaido and Kyushu are comparable, the actual yields of 45 and $28 \mathrm{tha}^{-1}$ differed much due to the difference in the length of the growing season of 144 and 92 days. At Okinawa, with lower input levels, the ratio was substantially lower. The potential yields in the table are mainly affected by the length of the growing season and solar radiation. The two sites in the Netherlands, although they have the same level of technology, show a large difference in the $\mathrm{A} / \mathrm{P}$ ratio. This is due to the lower water holding capacity of the low-yielding site. The difference within the USA is due to whether irrigation was applied or not. In South Africa, growers in the group of advanced industrial production achieve the lowest A/P ratio due to erratic weather patterns. Still larger yield gaps relative to the Netherlands and USA are shown for the other countries with lower levels of technology. Although actual yields will increase associated with increased $\mathrm{CO}_{2}$ concentration (Table 8), a still substantial further increase of the actual/potential yield ratio in Hokkaido is not expected due to the law of diminishing returns expressed by Von Liebig (1855): relative yields may still increase somewhat but its value will be less than the cost of the added input so it will depend on the price of the crop or of its input.

\section{Concluding Remarks}

The comparison of actual and potential yields has shown that the yield gap varies considerably between the various production sites in Japan. The spring crop in Nagasaki and the summer crops at Abashiri and Obihiro of Hokkaido, where growers largely depend on potato for their income, all have A/P ratios above 0.60 , but many prefectures, especially in the Kansai region, have low actual yields and achieve often less than one third of the potential. The crop here only minimally contributes to the farm income as is also reflected in the low occurrence of the crop here: a few hundred hectares per prefecture. The present findings also shows that there is a reason to explore the origin of the yield gap that may be attributed to the propagation material (variety, seed rate, age and health) and crop management (soil, fertilization and crop protection) because the other factors such as climate, planting and harvest time are accounted for by the current crop growth model. Higher yielding potato cyst nematode-resistant varieties, lengthening of the growing season and the beneficial effect of increased $\mathrm{CO}_{2}$ may reverse the present trend of decreasing yields at Hokkaido. A competitive advantage that all Japanese production regions have over most other regions in the world is the abundance of precipitation during the growing season making costly irrigation redundant.

Acknowledgments This study was made possible by a grant of Hoikkaido University allowing Dr. Haverkort to spend two months in 2015 at the Department of Agriculture.

Open Access This article is distributed under the terms of the Creative Commons Attribution 4.0 International License (http://creativecommons.org/licenses/by/4.0/), which permits unrestricted use, distribution, and reproduction in any medium, provided you give appropriate credit to the original author(s) and the source, provide a link to the Creative Commons license, and indicate if changes were made. 


\section{References}

AMeDAS (2015). https://en.wikipedia.org/wiki/Automated_Meteorological_Data_Acquisition_System. Accessed 3 Nov 2015

Anonymous (2011) Report on research program for evaluating the impact of global warming on the changes in agricultural productivity in Hokkaido for the decades 2030s. Miscellaneous publication of Hokkaido Research Organization. Agricultural Experimental Station. Number 39, 96 pp

Haverkort AJ, Franke AC, Engelbrecht AF, Steyn JM (2013) Climate change and potato production in contrasting South African agro-ecosystems. 1. Effects Land Water Use Efficiencies Potato Res 56:31-50

Haverkort AJ, Franke AC, Steyn JM, Pronk AA, Kooman PL (2015) A robust potato model: LINTULPOTATO-DSS. Potato Research 58:313-327 doi: 10.1007/s11540-015-9303-7

Haverkort AJ, Sandaña P, Kalazich J (2014) Yield gaps and ecological footprints of potato production systems in Chile. Potato Res 57:31-31

Hokkaido Government (2015) Report of crop growth situation (translated from Japanese). http://www.pref. hokkaido.lg.jp/gyosei/shicho/index.htm. Accessed 7 Nov 2015

IPCC (2013) Fifth assessment report - climate change 2013. www.ipcc.ch/report/ar5/wg1/. Assessed Jan 2016

Jaggard KW, Qi A, Ober ES (2010) Possible changes to arable crop yields by 2050. Phil Trans. doi:10.1098 /rstb.2010.0153

Kawakami K (1948) Introduction of potato crop (translated from Japanese). Yokendo Publisher, Tokyo, 324 pp

Kawakami T, Oohori H, Tajima K (2015) Seed potato production system in Japan, starting from foundation seed of potato. Breed Sci 66:17-25

Kurihara H, Nishikawa H, Tabata K, Okubo T (1963) Studies on relationship between cultural conditions and growing process in potato crop. Bulln Tohoku Natl Agric Exp Stn 28:143-200

MAFF (2010) Crop statistics, Ministry of Agriculture, Forest and Fishery in Japan. http://www.maff.go. jp/j/seisan/tokusan/imo/pdf/07.pdf. Accessed 1 Nov 2015

MAFF (2015) Ministry of Agriculture, Forest and Fishery in Japan. http://www.maff.go. jp/j/press/syouan/syokubo/150819.html). Accessed 1 Nov 2015

MeteoCrop DB (2015) http://meteocrop.dc.affrc.go.jp/real/top.php. Accessed 3 Nov 2015

Molahlehi L, Steyn JM, Haverkort AJ (2013) Potato crop response to genotype and environment in a subtropical highland agro-ecology. Potato Res 56:237-258

Mori M, Tsuda M, Mukojima N, Kobayashi A, Matsuura-Endo C, Ohara-Takada A, Zaidul ISM (1994) Characterization, evaluation and use of potato in Japan. (1994) MAFF International Workshop on Genetic Resources Root and Tuber Crops: 83-91

NARO (2010) List of planting systems among vegetables. (Translated from Japanese). Res Data NARO Inst Veg Tea Sci 5:1-310

Svubure O, Struik PC, Haverkort AJ, Steyn JM (2015) Yield gap analysis and resource footprints of Irish potato production systems in Zimbabwe. Field Crops Res 178:77-90

Uchida S, Taguchi K (1943) Potato. Bull Hokkaido Natl Agric Exp Station 62:1-129

Von Liebig J (1855) Die Grundsätze der Agriculturchemie, mit Rücksicht auf die in England angestelten Untersuchungen. Vieweg Braunschweig, 155 pp 